\title{
Neutralization of the edema-forming, defibrinating and coagulant effects of Bothrops asper venom by extracts of plants used by healers in Colombia
}

V. Núñez ${ }^{1}$, R. Otero ${ }^{1}$, J. Barona ${ }^{1}$, M. Saldarriaga ${ }^{1}$, R.G. Osorio ${ }^{1}$, R. Fonnegra ${ }^{1,2}$, S.L. Jiménez ${ }^{1,3}$, A. Díaz ${ }^{1}$ and J.C. Quintana ${ }^{1}$

\author{
${ }^{1}$ Grupo de Ofidismo y Escorpionismo, Facultad de Medicina, \\ ${ }^{2}$ Herbario, and ${ }^{3}$ Facultad de Química Farmacéutica, \\ Universidad de Antioquia, Medellín, Colombia
}

Correspondence

R. Otero

Centro de Investigaciones Médicas

Facultad de Medicina

Universidad de Antioquia

A.A. 1226, Medellín

Colombia

Fax: +57-4-263-1914

E-mail: rafaotero@epm.net.co

Research supported by the Instituto Colombiano para el Desarrollo de la Ciencia y la Tecnología Francisco José de Caldas (Colciencias) and by Universidad de Antioquia.

Received June 2, 2003 Accepted February 26, 2004

\begin{abstract}
We determined the neutralizing activity of 12 ethanolic extracts of plants against the edema-forming, defibrinating and coagulant effects of Bothrops asper venom in Swiss Webster mice. The material used consisted of the leaves and branches of Bixa orellana (Bixaceae), Ficus nymphaeifolia (Moraceae), Struthanthus orbicularis (Loranthaceae) and Gonzalagunia panamensis (Rubiaceae); the stem barks of Brownea rosademonte (Caesalpiniaceae) and Tabebuia rosea (Bignoniaceae); the whole plant of Pleopeltis percussa (Polypodiaceae) and Trichomanes elegans (Hymenophyllaceae); rhizomes of Renealmia alpinia (Zingiberaceae), Heliconia curtispatha (Heliconiaceae) and Dracontium croatii (Araceae), and the ripe fruit of Citrus limon (Rutaceae). After preincubation of varying amounts of each extract with either $1.0 \mu \mathrm{g}$ venom for the edema-forming effect or $2.0 \mu \mathrm{g}$ venom for the defibrinating effect, the mixture was injected subcutaneously $(s c)$ into the right foot pad or intravenously into the tail, respectively, to groups of four mice (18-20 g). All extracts (6.2-200 $\mu \mathrm{g} /$ mouse) partially neutralized the edema-forming activity of venom in a dose-dependent manner (58-76\% inhibition), with B. orellana, $S$. orbicularis, G. panamensis, B. rosademonte, and D. croatii showing the highest effect. Ten extracts (3.9-2000 $\mu \mathrm{g} /$ mouse) also showed $100 \%$ neutralizing ability against the defibrinating effect of venom, and nine prolonged the coagulation time induced by the venom. When the extracts were administered either before or after venom injection, the neutralization of the edema-forming effect was lower than $40 \%$ for all extracts, and none of them neutralized the defibrinating effect of venom. When they were administered in situ ( $s c$ at the same site $5 \mathrm{~min}$ after venom injection), the neutralization of edema increased for six extracts, reaching levels up to $64 \%$ for C. limon.
\end{abstract}

Key words

- Neutralization

- Edema

- Defibrination

- Coagulation

- Bothrops asper venom

- Plant extracts 


\section{Introduction}

More than $90 \%$ of the snakebites reported every year in Latin America are inflicted by snakes of the genus Bothrops $(1,2)$. Two of the most relevant signs of bothropic envenomation are edema and defibrination, which may contribute to local ischemic damage, hypotension and hemorrhage (3-5).

The antivenoms commonly used for the serotherapy of snakebites show a very limited efficacy in the neutralization of edema, not only due to the variety of components inducing this alteration, but also due to its rapid onset (6-8). Defibrinating (in vivo) and coagulant (in vitro) effects are produced by thrombin-like toxins present in the venom which induce fibrinogen consumption and incoagulable blood that may favor systemic bleeding (9).

In northwestern Colombia, $60 \%$ of snakebite victims are initially treated by traditional healers who use medicinal plants in different forms according to the clinical condition of the patient $(6,10,11)$. Thus, the experimental validation of such traditional knowledge is very important to elucidate the rational basis of its use. In the present study, we tested 12 ethanolic extracts of plants for their neutralizing ability against the edemaforming, defibrinating and coagulant effects of Bothrops asper venom. The extracts had previously demonstrated anti-lethal and/or anti-hemorrhagic capacity against $B$. atrox asper venom in mice $(12,13)$.

\section{Material and Methods}

\section{Mice, venom and extract preparation}

Swiss Webster mice weighing 18-20 g were used to determine the edema-forming and defibrinating effects of venom. B. asper venom was obtained by milking more than 40 specimens captured in Antioquia and Chocó, Northwestern Colombia. Venom was centrifuged and the supernatant lyophilized and stored at $-20^{\circ} \mathrm{C}$ until use.

The plants were collected together with traditional healers in rural communities from the Atrato River Valley (Antioquia and Chocó) and on the Pacific coast (Chocó) (Table 1), identified and deposited in the Herbarium of the Universidad de Antioquia in Medellín. After drying and crushing, individual samples of each part used were extracted with $96 \%$ ethanol at room temperature for 2 days. Extracts were concentrated to a semisolid paste using a BÜCHI - 124 rotavapor (Flawil, Switzerland), lyophilized for 4 days and stored at $-20^{\circ} \mathrm{C}$ until use (14).

\section{Edema-forming effect of venom and extracts}

Groups of four mice were injected subcutaneously $(s c)$ into the right foot pad with several quantities of either venom (0.25-4.0 $\mu \mathrm{g})$ or extract $(3.12-400 \mu \mathrm{g})$ dissolved in 50 $\mu l$ phosphate-buffered saline (PBS), $\mathrm{pH}$ 7.2. The left foot pad was similarly injected with $50 \mu \mathrm{l}$ PBS alone (control) according to the method of Yamakawa et al. (15), modified by Gutiérrez et al. (16). Edema was calculated as percentage of increase in the weight of the right foot injected with venom or extract compared to the left foot (PBS alone $=$ control $)$. The minimum edema-forming dose was the venom dose that induced $30 \%$ edema within $6 \mathrm{~h}$.

The minimum edema-forming dose of B. asper venom was $1.5 \pm 0.3 \mu \mathrm{g} / \mathrm{mouse}$, the dose that also induced intense hemorrhage. For this reason, a lower dose of venom (1.0 $\mu \mathrm{g}$ ) was chosen for the experiments of edema neutralization.

Except for Citrus limon, Tabebuia rosea, Ficus nymphaeifolia, Gonzalagunia panamensis and Dracontium croatii, all of the extracts dissolved in PBS, pH 7.2, and injected $s c$ into the foot pad induced edema at doses of 200 to $400 \mu \mathrm{g} / \mathrm{mouse}$, but none did so at lower doses. 


\section{Defibrinating effect of venom and extracts}

Groups of 4 mice were injected intravenously (iv) into the tail or intramuscularly (im) into the gastrocnemius muscle with several doses of either venom or extract dissolved in 0.2 or $0.1 \mathrm{ml} \mathrm{PBS,} \mathrm{pH} 7.2$, respectively. A control group of 4 mice received PBS alone under identical conditions. One or $2 \mathrm{~h}$ later, mice were anesthetized with halothane and bled to test coagulation status by the method of Theakston and Reid (17), modified by Gutiérrez et al. (18). The minimum defibrinating dose was the venom dose that produced $100 \%$ incoagulability in all mice either 1 or $3 \mathrm{~h}$ after $i v$ or $i m$ venom injection, respectively. The minimum defibrinating dose of $B$. asper venom was $1.1 \pm$ $0.3 \mu \mathrm{g} /$ mouse by the $i v$ route and $40 \mu \mathrm{g} /$ mouse by the im route. None of the extracts had defibrinating activity.

\section{Coagulant effect of venom}

The method described by Theakston and Reid (17) was followed, with small modifications. Briefly, $1.0 \mu \mathrm{g} B$. asper venom dissolved in $50 \mu \mathrm{PBS}$, pH 7.2, was added to human plasma $(0.3 \mathrm{ml})$ from healthy donors, preincubated at $37^{\circ} \mathrm{C}$ and the time required for plasma coagulation was determined.

\section{Neutralization of Bothrops asper venom effects}

In vitro experiments. Variable doses of each lyophilized extract (3.1-400 $\mu \mathrm{g} /$ mouse for edema, and 1.9-2000 $\mu \mathrm{g}$ for defibrination), were preincubated at $37^{\circ} \mathrm{C}$ for $30 \mathrm{~min}$ with fixed doses of venom $(1.0 \mu \mathrm{g}$ dissolved in $50 \mu \mathrm{l}$ PBS for edema, and $2.0 \mu \mathrm{g}$ dissolved in $200 \mu \mathrm{l}$ PBS for defibrination). Groups of 4 mice were then injected $s c$ or $i v$ with the mixture as described above. The control group received venom alone under identical conditions. The results are reported as percentage of edema neutralization within $6 \mathrm{~h}$, with the edema of the control group being considered $100 \%$. Neutralization of the defibrinating effect is reported as effective dose $100 \%\left(\mathrm{ED}_{100}\right)$, i.e., the extract dose that neutralized $100 \%$ of the defibrinating effect of venom in all mice within $1 \mathrm{~h}$.

For the neutralization of the coagulant activity of venom, a constant amount $(20 \mu \mathrm{g})$ of each lyophilized extract mixed with 1.0 $\mu \mathrm{g}$ venom dissolved in $50 \mu \mathrm{l}$ PBS, $\mathrm{pH} 7.2$, was incubated at $37^{\circ} \mathrm{C}$ for $30 \mathrm{~min}$. The mixture was then added to plasma $(300 \mu \mathrm{l})$ and the clotting time was recorded.

\section{In vivo experiments}

Edema neutralization. The extracts that demonstrated in vitro neutralizing ability were then independently administered to groups of 4 mice at different times, doses and routes as follows: 1) $0.5 \mathrm{mg}$ of each extract dissolved in PBS was administered orally (in $50 \mu \mathrm{l}$ ) or intraperitoneally (ip) (in $0.5 \mathrm{ml}$ ) either $60 \mathrm{~min}$ before or $5 \mathrm{~min}$ after venom injection $(1.0 \mu \mathrm{g} s c$ in the right foot pad); 2) $0.5 \mathrm{mg}$ of each extract dissolved in $0.2 \mathrm{ml}$ PBS, pH 7.2, was injected $i v$ either 15 min before or 5 min after venom injection; 3 ) the extract dose that induced the best in vitro neutralization of the edema-forming effect was dissolved in $50 \mu \mathrm{l}$ PBS and injected $s c$ (in situ) $5 \mathrm{~min}$ after venom injection $(1.0 \mu \mathrm{g}$ $s c$ into the right foot pad). Six hours later, mice were sacrificed by halothane inhalation and the percentage of edema neutralization was determined taking as $100 \%$ the edema of the control group (venom alone).

\section{Neutralization of the defibrinating effect}

A 2.0-mg aliquot of each extract dissolved in PBS was administered orally (in 50 $\mu \mathrm{l}$ ) or ip (in $0.5 \mathrm{ml}$ ) either $60 \mathrm{~min}$ before or 5 min after $i v$ injection of $2.0 \mu \mathrm{g}$ venom. In a second group of experiments, $1.0 \mathrm{mg}$ of each extract dissolved in $0.2 \mathrm{ml}$ PBS was administered $i v$ either $15 \mathrm{~min}$ before or $5 \mathrm{~min}$ after 
Figure 1. Dose/response curve of edema neutralization. Experiments were performed by preincubating 3.1-400 $\mu \mathrm{g}$ of extract and fixed doses $(1.0 \mu \mathrm{g})$ of venom for $30 \mathrm{~min}$ at $37^{\circ} \mathrm{C}$ (see Material and Methods). A, Brownea rosademonte extract; $B$, Bixa orellana extract; $C$, Trichomanes elegans extract; $D$, Citrus limon extract. Data are reported as the mean \pm SD for each experiment. the 2.0- $\mu \mathrm{g}$ iv venom injection. In a third group of experiments, variable doses (0.5$2.0 \mathrm{mg}$ ) of either extract were injected $\mathrm{im}$ (in situ) after the venom injection $(40 \mu \mathrm{g} \mathrm{im})$.

A control group of 4 mice received venom alone under identical conditions. One hour or $3 \mathrm{~h}$ after $i v$ or $i m$ venom injection, respec-
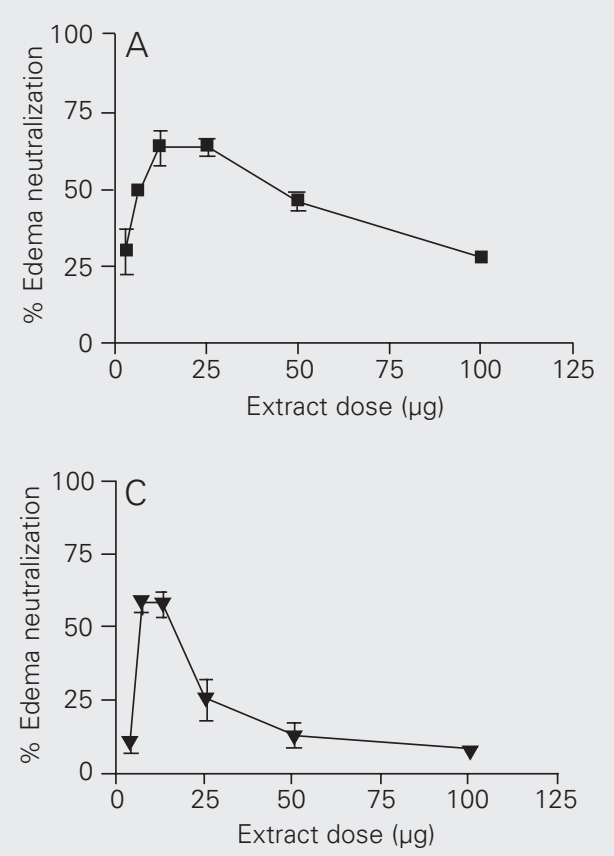

tively, neutralization of the defibrinating effect of venom was tested as described above.

\section{Polyacrylamide gel electrophoresis (SDS- PAGE)}

\section{SDS-PAGE was performed on $15 \%$ poly-}
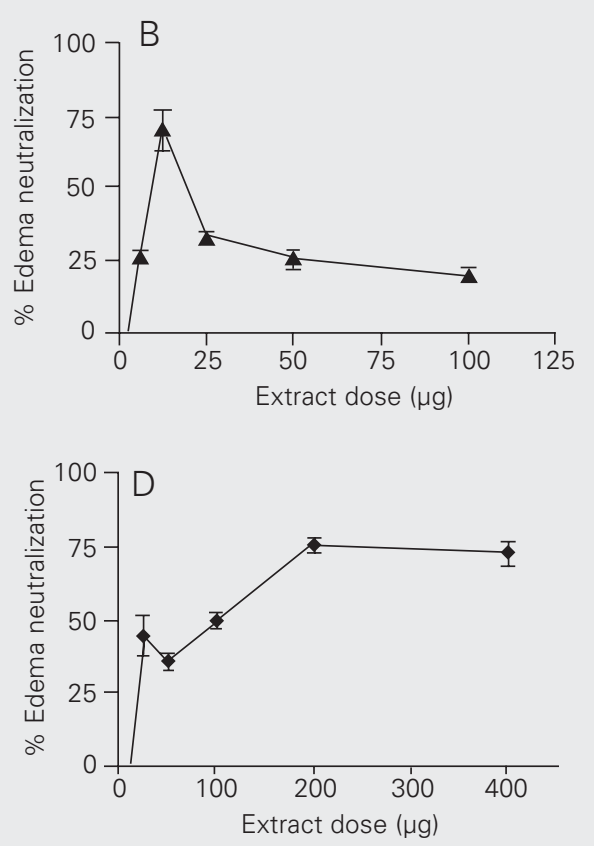

Table 1. In vitro neutralizing capacity of plant extracts against the edema-forming and defibrinating effects of Bothrops asper venom.

\begin{tabular}{|c|c|c|c|}
\hline Family/species (voucher specimen) & Part used & $\begin{array}{l}\text { Extract dose }(\mu \mathrm{g} / \text { mouse })^{*} \\
\text { edema neutralization }(\%)\end{array}$ & $\begin{array}{c}\text { Neutralization of } \\
\text { defibrination }\left(E D_{100}\right)^{* *}(\mu \mathrm{g})\end{array}$ \\
\hline Bixaceae/Bixa orellana L. (RF 6485) & $L, B R$ & $12.5(72 \pm 5)^{a}$ & 3.9 \\
\hline Caesalpiniaceae/Brownea rosademonte Berg. (RF 6455) & SB & $12.5(64 \pm 6)^{a}$ & 31.2 \\
\hline Rutaceae/Citrus limon (L.) Burm.f (RF 6736) & RF & $200(76 \pm 6)^{b}$ & NNA \\
\hline Araceae/Dracontium croatii Zhu. (RF 6245) & $\mathrm{RH}$ & $6.2(62 \pm 10)^{a}$ & 2000 \\
\hline Moraceae/Ficus nymphaeifolia Miller (RF 6448) & $\mathrm{L}, \mathrm{BR}, \mathrm{ST}$ & $200(64 \pm 2)^{c}$ & 500 \\
\hline Rubiaceae/Gonzalagunia panamensis (Cav.) Schumm. (RF 6405) & $L, B R, S T$ & $12.5(63 \pm 8)^{a}$ & 500 \\
\hline Heliconiaceae/Heliconia curtispatha Petersen (RF 6486) & $\mathrm{RH}$ & $25(73 \pm 6)^{a}$ & 250 \\
\hline Polypodiaceae/Pleopeltis percussa (Cav.) Hook \& Grev. (RF 6410) & WP & $25(68 \pm 8)^{a}$ & 31.2 \\
\hline Zingiberaceae/Renealmia alpinia (Rottb.) Maas (RF 6456) & $\mathrm{RH}$ & $100(66 \pm 3)^{c}$ & 250 \\
\hline Loranthaceae/Struthanthus orbicularis (H.B.K.) Blume (RF 6422) & $L, B R$ & $12.5(65 \pm 2)^{\mathrm{a}}$ & $>2000$ \\
\hline Bignoniaceae/Tabebuia rosea (Bertold.) DC. (RF 6458) & SB & $200(58 \pm 5)^{c}$ & 1000 \\
\hline Hymenophyllaceae/Trichomanes elegans L.C. Rich (RF 6744) & WP & $6.2(58 \pm 2)^{a}$ & 31.2 \\
\hline
\end{tabular}

Voucher specimen Herbarium of the Universidad de Antioquia: RF = Ramiro Fonnegra and others (collectors). Part used: $B R=b r a n c h e s ; ~ L=$ leaves; $\mathrm{RF}=$ ripe fruits; $\mathrm{RH}=$ rhizomes; $\mathrm{SB}=$ stem bark; $\mathrm{ST}=$ stem; $\mathrm{WP}=$ whole plant. $\mathrm{NNA}=$ no neutralizing ability.

Data are reported as the mean $\pm S D$ of three experiments. Values with different superscripts are significantly different $(P<0.05)$ in each group; first group $=$ extract doses $\leq 25 \mu \mathrm{g}$; second group $=$ extract doses $>25 \mu \mathrm{g}$.

${ }^{*}$ Extract dose with the maximal neutralizing effect. ${ }^{*}$ Effective dose $100 \%\left(E D_{100}\right)$ is the extract dose that neutralized $100 \%$ the defibrinating effect of venom in all mice. 
acrylamide gels (19). The mixture of $B$. asper venom and each extract $(1: 10 \mathrm{w} / \mathrm{w})$ was preincubated at $37^{\circ} \mathrm{C}$ for $30 \mathrm{~min}$. Then, $20 \mu \mathrm{l}$ of each mixture was run at $150 \mathrm{~V}$ for $1 \mathrm{~h}$. The proteins were stained with Coomassie blue.

\section{Statistical analysis}

Results are reported as means \pm SD. Mean values of venom neutralization by the extracts were compared by analysis of variance (two-way ANOVA) using the STATISTICA 98 software (StatSoft, Tulsa, OK, USA). Differences were analyzed by the NewmanKeuls test. The Dunnett test was used to compare the mean values obtained for the neutralization of the coagulant effect to a control. Differences were considered significant when $\mathrm{P}<0.05$.

\section{Results}

\section{In vitro neutralization}

All extracts were partially effective in a dose-dependent manner in neutralizing the edema-forming effect of $B$. asper venom at doses $\leq 200 \mu \mathrm{g} /$ mouse (Figure 1 and Table $1)$. The extracts with higher neutralizing potency at low doses $(6.2-25 \mu \mathrm{g} /$ mouse $)$ were those of Trichomanes elegans $(58 \pm 2 \%), D$. croatii $(62 \pm 10 \%)$, Bixa orellana $(72 \pm 5 \%)$, Brownea rosademonte (64 $\pm 6 \%)$, Struthanthus orbicularis $(65 \pm 2 \%)$, and G. panamensis $(63 \pm 8 \%)$. The extracts of $C$. limon, Renealmia alpinia, $T$. rosea, and $F$. nymphaeifolia needed higher doses to produce a similar neutralizing effect $(\mathrm{P}<0.05)$. Nevertheless, the two-phase response observed in the neutralization curve indicated that the preincubated mixture of venom plus extract also induced edema in mice at variable doses according to the extract $(>12.5 \mu \mathrm{g} /$ mouse; Figure 1).

Additionally, 10 of the 12 extracts had $100 \%$ neutralizing ability against the defibrinating effect of venom. The $C$. limon extract was devoid of neutralizing capacity against this effect, and $S$. orbicularis extract was only partially effective (25\%) at doses up to $2000 \mu \mathrm{g} /$ mouse (Table 1). The extract with highest neutralizing potency was that of $B$. orellana.

One microgram of venom induced coagulation of human plasma in $17 \pm 3 \mathrm{~s}$. Nine extracts significantly prolonged the coagulation time when preincubated with the venom $(\mathrm{P}<0.001)$. Six of them (B. rosademonte, Pleopeltis percussa, T. elegans, S. orbicularis, B. orellana and Heliconia curtispatha) prolonged the coagulation time beyond $60 \mathrm{~s}$ (Figure 2).

\section{In vivo neutralization}

When the extracts were independently administered by the oral, ip or $i v$ route, either 15 or $60 \mathrm{~min}$ before venom injection, the neutralization of the edema-forming effect

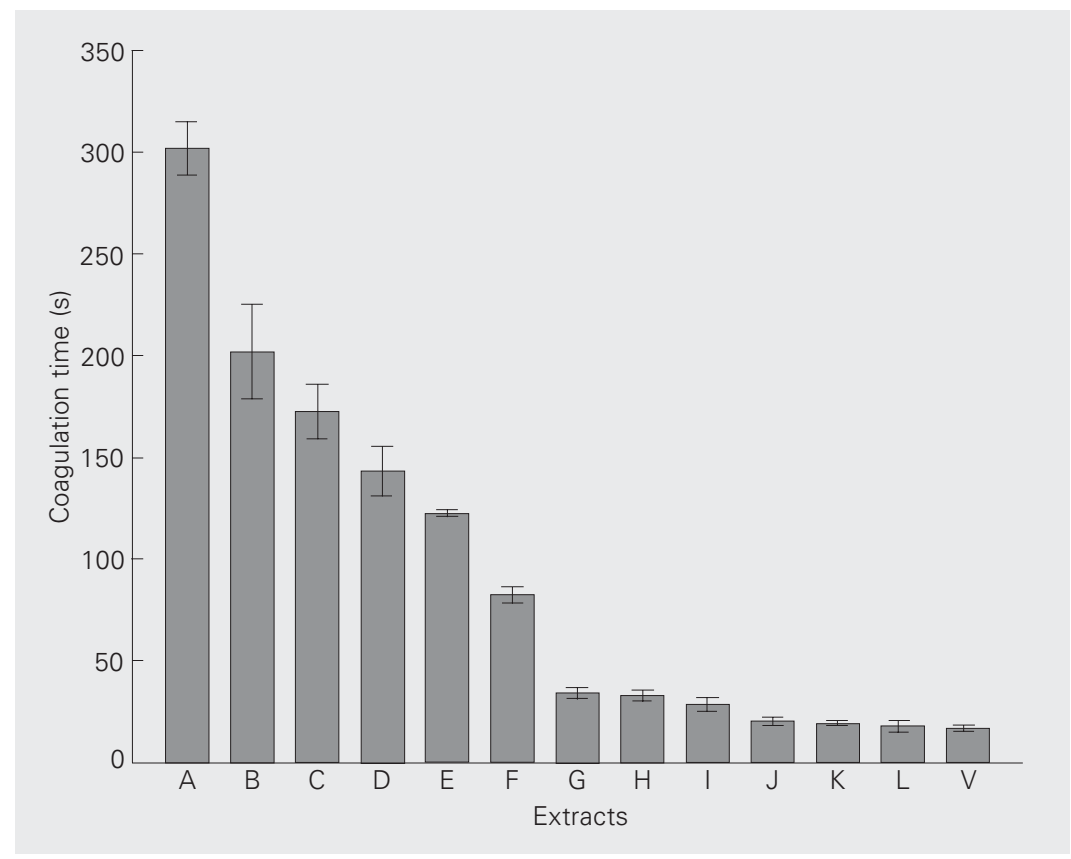

Figure 2. Coagulation time. Fixed doses of each extract $(20 \mu \mathrm{g})$ and Bothrops asper venom $(1.0 \mu \mathrm{g})$ were preincubated at $37^{\circ} \mathrm{C}$ for $30 \mathrm{~min}$. Then, $50 \mu \mathrm{l}$ of the mixture was added to 300 $\mu \mathrm{l}$ of citrated human plasma and the coagulation time was determined. A, Heliconia curtispatha; B, Pleopeltis percussa; C, Brownea rosademonte; D, Bixa orellana; E, Trichomanes elegans; F, Struthanthus orbicularis; G, Gonzalagunia panamensis; H, Ficus nymphaeifolia; I, Tabebuia rosea; J, Renealmia alpinia; K, Dracontium croatii; L, Citrus limon; $V=$ venom alone. Data are reported as the mean $\pm S D$ of three determinations. 
of venom varied according to the extract, dose and route of administration (data not shown). Similarly, when the extracts were administered by these routes $5 \mathrm{~min}$ after venom injection, they also showed variable neutralizing ability. Overall, neutralization was lower than $40 \%$ for all extracts (Table 2). Nevertheless, when the extracts were administered in situ immediately after venom injection, all of them showed increased edema neutralization (Table 2). The C. limon ex- tract showed the highest neutralization $(64 \%)$ by this route $(\mathrm{P}<0.001)$. None of the extracts neutralized the defibrinating effect of $B$. asper venom when they were individually administered by the oral, ip, iv or in situ route, either before or after venom injection (data not shown).

\section{Electrophoretic analysis}

After preincubation of extract and venom,

Table 2. Neutralization of the edema-forming effect of Bothrops asper venom in experiments with independent administration of extract and venom.

\begin{tabular}{lrrrr}
\hline Plant extract* & \multicolumn{4}{c}{ \% Neutralization } \\
\cline { 2 - 5 } & \multicolumn{1}{c}{ Oral } & ip & iv & In situ* \\
\hline Bixa orellana L. & $16 \pm 5$ & $25 \pm 3$ & $24 \pm 3$ & $28 \pm 4^{\mathrm{c}}$ \\
Brownea rosademonte Berg. & $15 \pm 1$ & $21 \pm 2$ & $18 \pm 2$ & $45 \pm 7^{\mathrm{b}}$ \\
Citrus limon (L.) Burm.f & $33 \pm 9$ & $17 \pm 4$ & $28 \pm 5$ & $64 \pm 6^{\mathrm{a}}$ \\
Dracontium croatii Zhu. & $8 \pm 3$ & $7 \pm 1$ & $28 \pm 1$ & $3 \pm 2^{\mathrm{e}}$ \\
Ficus nymphaeifolia Miller & $8 \pm 3$ & $30 \pm 0$ & $16 \pm 4$ & $27 \pm 1^{d}$ \\
Gonzalagunia panamensis (Cav.) Schumm & $23 \pm 5$ & $20 \pm 7$ & $14 \pm 3$ & $26 \pm 8^{\mathrm{d}}$ \\
Heliconia curtispatha Petersen & $13 \pm 1$ & $14 \pm 1$ & $19 \pm 4$ & $48 \pm 4^{\mathrm{b}}$ \\
Pleopeltis percussa (Cav.) Hook \& Grev. & 0 & $13 \pm 5$ & $11 \pm 1$ & $29 \pm 5^{\mathrm{c}}$ \\
Renealmia alpinia (Rottb.) Maas & $21 \pm 6$ & $12 \pm 1$ & $28 \pm 2$ & $40 \pm 8^{\mathrm{b}}$ \\
Struthanthus orbicularis (H.B.K.) Blume & $19 \pm 4$ & $28 \pm 6$ & 0 & $24 \pm 7^{\mathrm{d}}$ \\
Tabebuia rosea (Bertold.) DC. & $16 \pm 1$ & $35 \pm 6$ & $29 \pm 6$ & $31 \pm 4^{\mathrm{c}}$ \\
Trichomanes elegans L.C. Rich & $32 \pm 6$ & $24 \pm 3$ & $18 \pm 4$ & $48 \pm 4^{\mathrm{b}}$ \\
\hline
\end{tabular}

The edema in the control group (venom alone) was $14.6 \pm 2 \%$. Values with different superscripts are significantly different $(P<0.05)$.

${ }^{*}$ A 0.5-mg aliquot of each extract was administered (orally, ip or iv) 5 min after sc venom injection (1.0 $\mu \mathrm{g}$ ) into the right foot pad of mice. **The extract dose that induced the best in vitro neutralization of the edemaforming effect was injected sc (in situ) 5 min after the venom.

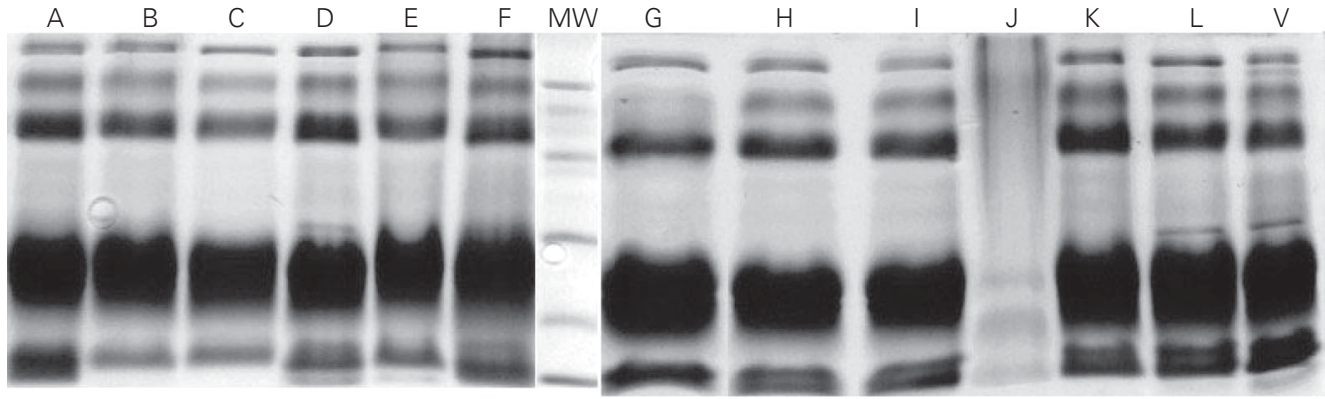

Figure 3. SDS-PAGE of Bothrops asper venom after incubation with plant extracts $\left(1: 10, \mathrm{w} / \mathrm{w}, 30 \mathrm{~min}, 37^{\circ} \mathrm{C}\right) . A$, Gonzalagunia panamensis; B, Pleopeltis percussa; $C$, Struthanthus orbicularis; D, Dracontium croatii; E, Brownea rosademonte; F, Tabebuia rosea; G, Citrus limon; H, Trichomanes elegans; I, Ficus nymphaeifolia; J, Heliconia curtispatha; K, Bixa orellana; L, Renealmia alpinia; V = venom alone; $\mathrm{MW}=$ molecular weight markers $(97.4,66$, $45,31,21,14.4 \mathrm{kDa})$. 
only one of the 12 extracts (H. curtispatha) induced conspicuous changes in the electrophoretic pattern of venom (Figure 3). All experiments were repeated five times.

\section{Discussion}

Some of the factors associated with traditional medicine practices for snakebites in Colombia are social problems, geographical difficulties, and the insufficient production, supply or distribution of antivenoms. Thus, $60 \%$ of snakebite victims are initially treated by healers who use medicinal plants administered either by the oral route or by external baths, vapor and poultices applied to the affected extremity (11). Plants constitute rich sources of novel compounds with a variety of pharmacological activities. Therefore, experimental validation of the traditional use of plants is important and can facilitate the development of low-cost phytotherapeutic agents (20).

In viper bites, edema is the result of the synthesis of potent autocoids or eicosanoids triggered by enzymatic components of the venom, as well as by the damage in the microvasculature with plasma extravasation and the release of cytokines. Chaves et al. (21) demonstrated that pretreatment with indomethacin (an inhibitor of the cyclooxygenase pathway), dexamethasone and mepacrine (two drugs that inhibit phospholipase $\mathrm{A}_{2}$ activity by different mechanisms), reduced the edema induced by $B$. asper venom. Thus, the edema induced by $B$. asper venom in the mouse foot pad model is mediated, at least in part, by phospholipase $\mathrm{A}_{2}$ activity and by eicosanoid products.

The rapid neutralization of venom in the bloodstream does not guarantee the halting of edema progression within a short time. In several experimental and clinical trials it has been demonstrated that antivenoms are of limited value to stop edema progression within the first 12-24 h of treatment, while they are highly efficient in restoring blood coagulation status within the same time in- terval $(7,22,23)$

Several reports have shown that plantderived compounds with activity on arachidonic acid metabolism, lead to a marked inhibition of edema. Some of them have been characterized as inhibitors of cyclooxygenase and lipoxygenase activities (24). Additionally, some plants active against the lethal effect of snake venoms $(25,26$, present study) are also active against the edema induced by venoms. The herbal compound (2OH-4-methoxy benzoic acid) isolated from the root extract of Hemidesmus indicus R. BR effectively neutralized the inflammation induced by Vipera russelli venom in male albino mice and reduced the cotton pelletinduced granuloma in rats (27). The Casearia sylvestris (Flacourtiaceae) extract inhibited by $50 \%$ the edema-inducing activity of both whole venom and myotoxin II of B. moojeni when assayed in the mouse foot pad model in preincubation experiments (28).

In the present study, 12 extracts which had previously demonstrated in vitro an antilethal and/or antihemorrhagic effect against $B$. asper venom $(12,13)$ also showed in vitro neutralizing ability against the edemaforming effect. When the extracts were administered individually (in vivo experiments) by the oral, ip or $i v$ route they showed a low, but significant neutralizing ability against edema. This capacity was increased for six extracts when they were injected in situ. This may indicate that close contact between the extract and venom is essential for a maximal neutralizing effect.

Venoms of vipers such as $B$. asper have in vitro coagulant effect and in vivo defibrinating effect on human plasma $(3,9,17)$. Accordingly, ten of the extracts studied here completely neutralized the defibrinating effect of venom and nine neutralized the coagulant effect in experiments with preincubation of venom and extract. Five of them, with the highest neutralizing capacity against the defibrinating effect of venom (B. orellana, $B$. rosademonte, $P$. percussa, $T$. elegans, $H$. 
curtispatha) also showed high neutralizing potency against the coagulant effect (Table 1, Figure 2).

Nevertheless, the extracts were unable to neutralize the defibrinating effect of venom when they were administered before or after venom injection, even when they were administered almost simultaneously at the same site of venom injection. The lack of this neutralizing ability may be related to the fact that low concentrations of venom are sufficient to induce defibrination, as well as to the rapid action of thrombin-like components (29).

Although the mechanism of action of these extracts is unknown, a change in the electrophoretic pattern of $B$. asper venom induced by the $H$. curtispatha extract indicates that protein hydrolysis is a potential mechanism. When varying the incubation time of venom and extract $(5,15,30$ and 60 min; results not shown) a similar electrophoretic pattern was obtained. Other mechanisms of action (inhibition of the catalytic activity of snake venoms and their enzymes, i.e., phospholipase $\mathrm{A}_{2}$, metalloproteinase inhibition by the presence of metal-chelator substances in the extracts) have been proposed for plant extracts in venom neutralization (12,13,30-32). With the exception of $C$. limon, D. croatii and $F$. nymphaeifolia, all the extracts studied here showed neutralizing ability against phospholipase $\mathrm{A}_{2}$ activity (indirect hemolysis) of $B$. asper venom as well as partial neutralization of myonecrosis induced by this venom (12, and Otero R, Núñez V, Barona J, Jiménez S, Fonnegra R and Osorio RG, unpublished observations).

Despite the reduction of the neutralizing capacity of the extracts against the toxic activities of $B$. asper venom when they were administered individually, the extracts could be used in combination with serotherapy in the treatment of viper bites, mainly as palliative treatment of some local signs of envenomation such as edema, hemorrhage and myonecrosis (13, and Otero R, Núñez V, Barona J, Jiménez S, Fonnegra R and Osorio RG, unpublished observations, present study). This might be particularly true if the extract is administered very soon at the same site of venom injection.

\section{References}

1. Fan HW \& Cardoso JLC (1995). Clinical toxicology of snakebite in South America. In: Meier J \& White J (Editors), Handbook of Clinical Toxicology of Animal, Venoms and Poisons. CRC Press, Boca Raton, FL, USA, 667-688.

2. Gutiérrez JM (1995). Clinical toxicology of snakebite in Central America. In: Meier J \& White J (Editors), Handbook of Clinical Toxicology of Animal, Venoms and Poisons. CRC Press, Boca Raton, FL, USA, 645-665.

3. Rosenfeld G (1971). Symptomatology, pathology and treatment of snake bites in South America. In: Bucherl W \& Buckley E (Editors), Venomous Animals and Their Venoms. Academic Press, New York, 345-381.

4. Warrell DA (1995). Clinical toxicology of snakebite in Asia. In: Meier $\mathrm{J} \&$ White J (Editors), Handbook of Clinical Toxicology of Animal, Venoms and Poisons. CRC Press, Boca Raton, FL, USA, 493-594.

5. Otero R, Gutiérrez J, Mesa MB et al. (2002). Complications of Bothrops, Porthidium, and Bothriechis snakebites in Colombia. A clinical and epidemiological study of 39 cases attended in a university hospital. Toxicon, 40: 1107-1114.

6. Otero R, Tobón GS, Gómez LF, Osorio RG, Valderrama R, Hoyos D, Urreta JE, Molina S \& Arboleda JJ (1992). Accidente ofídico en Antioquia y Chocó. Aspectos clínicos y epidemiológicos (marzo de 1989-febrero de 1990). Acta Médica Colombiana, 17: 229-249.
7. Otero-Patiño R, Cardoso JLC, Higashi HG et al. (1998). A randomized, blinded, comparative trial of one pepsin-digested and two whole IgG antivenoms for Bothrops snake bites in Urabá, Colombia. American Journal of Tropical Medicine and Hygiene, 58: 183-189.

8. Lomonte B, Tarkowski A \& Hanson HA (1993). Host response to Bothrops asper snake venom: Analysis of edema formation, inflammatory cells, and cytokine release in mouse model. Inflammation, 17: 93-105.

9. Kamiguti AS \& Cardoso JLC (1989). Haemostatic changes caused by the venoms of South American snakes. Toxicon, 27: 955-963.

10. Otero R, Valderrama R, Osorio RG \& Posada LE (1992). Programa de atención primaria del accidente ofídico. Una propuesta para Colombia. latreia, 5: 96-102.

11. Otero R, Fonnegra R, Jiménez SL et al. (2000). Snakebites and ethnobotany in the northwest region of Colombia. Part I: Traditional use of plants. Journal of Ethnopharmacology, 71: 493-504.

12. Otero R, Núñez $V$, Jiménez SL, Fonnegra R, Osorio RG, García ME \& Díaz A (2000). Snakebites and ethnobotany in the northwest region of Colombia. Part II: Neutralization of lethal and enzymatic effects of Bothrops atrox venom. Journal of Ethnopharmacology, 71: 505-511.

13. Otero R, Núñez $V$, Barona J, Fonnegra R, Jiménez SL, Osorio RG, Saldarriaga M \& Díaz A (2000). Snakebites and ethnobotany in the 
northwest region of Colombia. Part III: Neutralization of the haemorrhagic effect of Bothrops atrox venom. Journal of Ethnopharmacology, 73: 233-241.

14. Weniger $B$ (1991). Theory and instrumentation involved with extraction, control, quality insurance and registration of natural products. In: First International Advanced Course on Technology and Control of Drugs, Perugia, Italy, 31-40.

15. Yamakawa M, Nozaky M \& Hokama Z (1976). Fractionation of sakishimahabu (Trimeresurus elegans) venom and lethal, hemorrhagic and edema-forming activities of the fractions. In: Ohsaka A, Hayashi K \& Sawai Y (Editors), Toxins: Animal, Plant and Microbial. Plenum Press, New York, 97-109.

16. Gutiérrez JM, Rojas G, Lomonte B, Gene JA \& Cerdas L (1986). Comparative study of the edema-forming activity of Costa Rican snake venoms and its neutralization by polyvalent antivenom. Comparative Biochemistry and Physiology, 85C: 171-175.

17. Theakston RDG \& Reid HA (1983). Development of simple standard assay procedures for the characterization of snake venoms. Bulletin of the World Health Organization, 61: 949-956.

18. Gutiérrez JM, Rojas G \& Cerdas L (1987). Ability of a polyvalent antivenom to neutralize the venom of Lachesis muta melanocephala, a new Costa Rican subspecies of the Bushmaster. Toxicon, 25: 713-720

19. Laemmli UK (1970). Cleavage of structural proteins during the assembly of the head of bacteriophage T4. Nature, 227: 680-685.

20. Elisabetsky E (1991). Sociopolitical, economical and ethical issues in medicinal plant research. Journal of Ethnopharmacology, 32: 235239.

21. Chaves F, Barboza M \& Gutiérrez JM (1995). Pharmacological study of edema induced by venom of the snake Bothrops asper (terciopelo) in mice. Toxicon, 33: 31-39.

22. Otero R, Gutiérrez JM, Núñez V et al. (1996). A randomized doubleblind clinical trial of two antivenoms in patients bitten by Bothrops atrox in Colombia. Transactions of the Royal Society of Tropical Medicine and Hygiene, 90: 696-700.

23. Otero R, Gutiérrez JM, Rojas G et al. (1999). A randomized blinded clinical trial of two antivenoms, prepared by caprylic acid or ammo- nium sulphate fractionation of IgG, in Bothrops and Porthidium snake bites in Colombia: Correlation between safety and biochemical characteristics of antivenoms. Toxicon, 37: 895-908.

24. Mors WB, Nascimento MC, Ruppelt BM \& Alvares N (2000). Plant natural products active against snake bite - the molecular approach. Phytochemistry, 55: 627-642.

25. Alam MI, Auddy B \& Gomes A (1994). Isolation, purification and partial characterization of viper venom inhibiting factor from the root extract of the Indian medicinal plant sarsaparilla (Hemidesmus indicus $\mathrm{R}$. Br.). Toxicon, 32: 1551-1557.

26. Melo PA, Nascimento MC, Mors WB \& Suarez-Kurtz G (1994). Inhibition of the myotoxic and hemorrhagic activities of crotalid venoms by Eclipta prostrata (Asteraceae) extracts and constituents. Toxicon, 32: 595-603.

27. Alam MI \& Gomes A (1998). Viper venom-induced inflammation and inhibition of free radical formation by pure compound (2-hydroxy-4methoxy benzoic acid) isolated and purified from anantamul (Hemidesmus indicus R. BR) root extract. Toxicon, 36: 207-215.

28. Borges M, Soares AM, Rodrigues VM et al. (2000). Effects of aqueous extract of Casearia sylvestris (Flacourtiaceae) on actions of snake and bee venoms and on activity of phospholipases A2. Comparative Biochemistry and Physiology, 127: 21-30.

29. Ho M, Warrell DA, Looareesuwan S, Phillips RE, Chanthavanich $P$, Karbwang J, Supanaranond W, Viravan C, Hutton RA \& Vejcho S (1986). Clinical significance of venom antigen levels in patients envenomed by the Malayan pit viper (Calloselasma rhodostoma). American Journal of Tropical Medicine and Hygiene, 35: 579-587.

30. Gowda TV (1997). Interaction of snake venom phospholipases A2 with plant isolates. In: Kini RM (Editors), Venom Phospholipase A2 Enzymes. Wiley, Chichester, UK, 205-221.

31. Melo PA \& Ownby CL (1999). Ability of wedelolactone, heparin, and para-bromophenacyl bromide to antagonize the myotoxic effects of two crotaline venoms and their PLA2 myotoxins. Toxicon, 37: 199215.

32. Duke J (1998). Phytochemical and ethnobotanical databases. <http:/ /www.ars-grin.gov/cgi-bin/duke/ethnobotuse.pl>. 